\title{
Tinggi Badan dan Usia Tulang Sindrom Nefrotik yang Mendapat Terapi Steroid Jangka Panjang
}

\author{
K Dewi Kumara Wati, Ketut Suarta, Soetjiningsih
}

\begin{abstract}
Pasien SN anak akan sering mendapat steroid yang memiliki efek samping seperti obesitas, penekanan pertumbuhan, hipertensi serta osteoporosis Tujuan Penelitian untuk menilai tinggi badan dan usia tulang pasien sindrom nefrotik yang mendapat terapi steroid jangka panjang dan mengetahui hubungannya dengan dosis kumulatif, lama terapi dan jumlah frekuensi. Retrospektif, deskriptif analitik, dengan subjek pasien sindrom nefrotik yang dirawat di Laboratorium Ilmu Kesehatan Anak RSUP Denpasar antara 1 Januari 1998 hingga 31 Juli 2000. Data diambil dari rekam medik sedangkan penentuan tinggi badan dan usia tulang dilakukan saat penelitian. Analisis regresi linier dilakukan untuk melihat hubungan antara tinggi badan dan usia tulang dengan dosis kumulatif, lama terapi, serta jumlah relaps. Kemaknaan ditentukan dengan $p<0.05$. Terdapat 16 pasien, dengan usia 7,3 tahun $( \pm 3,3)$, rerata dosis kumulatif steroid 4,1 $\mathrm{mg}( \pm 2730)$, lama terapi 9,6 bulan $( \pm 2,4)$, rerata tinggi badan terhadap standar $97 \%( \pm 4,8)$, D usia tulang $+8,3$ bulan $( \pm 9,7)$. Tinggi badan tidak mempunyai hubungan dengan dosis steroid kumulatif, lama terapi maupun jumlah relaps $(r=0.16, p>0.05)$. Usia tulang tidak mempunyai hubungan, baik dengan dosis steroid kumulatif, lama terapi, maupun jumlah relaps $(\mathrm{r}=0.39, \mathrm{p}>0.05)$. Tinggi badan dan usia tulang pasien sindrom nefrotik pada penelitian ini tidak mempunyai hubungan dengan dosis kumulatif dan lama terapi steroid, maupun jumlah relaps.
\end{abstract}

Kata kunci: tinggi badan, usia tulang, steroid, sindrom nefrotik

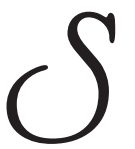

indrom nefrotik (SN) merupakan penyakit yang sering ditemukan di Indonesia. Angka kejadian SN pada anak tidak diketahui pasti, namun diperkirakan pada anak berusia di bawah 16 tahun berkisar antara 2-7 kasus per tahun pada setiap 1000.000 anak. ${ }^{1}$ Sindrom nefrotik tanpa disertai kelainan sistemik disebut $\mathrm{SN}$ primer, ditemukan pada $90 \%$ kasus $\mathrm{SN}$ anak. ${ }^{1}$ Berdasarkan kelainan histopatologis, SN pada anak yang paling banyak ditemukan adalah jenis kelainan

(Dr. K Dewi Kumara Wati, SpA, Dr. Ketut Suarta, Sp.A(K), Prof. Dr. Soetjiningsih, Sp.A(K)). Ilmu Kesehatan Anak FK UNUD /RSUP Denpasar.

Alamat korespondensi:

Dr. K Dewi Kumara Wati, SpA.

Ilmu Kesehatan Anak FK UNUD /RSUP Denpasar, Jl. Pulau Nias. Bali.

Telepon: 0361-222141/222142, Fax.: 0361-244038/24556. minimal. International Study of Kidney Disease in Children (ISKDC) melaporkan 76\% SN pada anak adalah kelainan minimal. ${ }^{1}$

Sebelum pertengahan abad ke-20, mortalitas SN sangat tinggi, umumnya pasien meninggal akibat sepsis, peritonitis, atau gizi buruk. Penggunaan antibiotik dan steroid menurunkan mortalitas penyakit ini secara drastis hingga 2,5-20\%. ${ }^{2}$ Steroid (prednison) merupakan imunosupresan yang banyak dipakai pada kasus $\mathrm{SN}$ anak. Obat ini merupakan pilihan pertama, karena mampu menginduksi remisi proteinuria dan melindungi fungsi ginjal. Namun demikian, pada SN yang sensitif terhadap steroid tidak jarang akan terjadi relaps. International Study of Kidney Disease in Children (ISKDC) melaporkan kejadian relaps sebanyak 60\%, bahkan penelitian lain melaporkan sampai 76-97\%, dengan angka relaps sering (frequent relapser) mencapai $50 \%$. 
Dengan demikian, kasus SN anak akan sering mendapat steroid. Selain memiliki keuntungan yang telah disebut di atas, steroid juga memiliki efek samping seperti: obesitas, gangguan pertumbuhan, hipertensi serta osteoporosis. ${ }^{3}$ Pengaruh steroid yang merugikan terhadap pertumbuhan telah dilaporkan oleh Kitamura, berupa tinggi badan pasien yang mendapat steroid saat usia 12-16 tahun berada di bawah mean-2SD dan 10 $\mathrm{cm}$ di bawah tinggi badan yang diharapkan. ${ }^{4}$ Tsau, dkk. melaporkan sebanyak 5,7\% kasus SN dengan relaps jarang mengalami gangguan pertumbuhan dengan terapi steroid, sedangkan pada mereka dengan relaps sering gangguan pertumbuhan mencapai angka 40,6\%. ${ }^{5}$ Rees, dkk. menemukan kasus dengan SN sensitif steroid memiliki deviasi tinggi badan yang bermakna terhadap usia kronologis. ${ }^{6}$

Berdasarkan hal tersebut di atas, dilakukan penelitian untuk mengetahui adanya gangguan pertumbuhan, melalui pengukuran tinggi badan dan usia tulang pada pasien SN yang mendapat terapi steroid jangka panjang yang pernah dirawat di Bagian Anak RSUP Denpasar.

\section{Metodologi}

Penelitian dilakukan di Poliklinik Nefrologi Anak RSUP Denpasar, antara 1 Januari 1998 hingga 31 Juli 2000 , terhadap pasien SN yang pernah dirawat di Bagian Anak RSUP Denpasar. Penelitian ini merupakan penelitian retrospektif deskriptif analitik. Data dikumpulkan secara retrospektif, potong lintang pada seri kasus, yang didapatkan melalui catatan medik. Data rekam medik yang dikumpulkan meliputi umur, jenis kelamin, status gizi, respons terhadap steroid, jumlah dan jenis relaps, lama terapi dan dosis kumulatif steroid yang dikonsumsi sejak awal pemberian steroid hingga saat dilakukan penelitian. Pengukuran tinggi badan (TB) dan usia tulang dilakukan pada saat penelitian. Semua pasien yang mendapat terapi sesuai modifikasi ISKDC selama lebih dari 6 bulan, diikutkan dalam penelitian. Sedangkan mereka yang disertai dengan gagal ginjal kronik, penyakit dengan potensi gangguan pertumbuhan, atau mendapat terapi hormonal selain setroid, tidak diikutkan dalam penelitian.

Definisi operasional yang digunakan pada penelitian ini ialah: terapi steroid jangka panjang bila mengkonsumsi steroid untuk jangka waktu lebih dari 6 bulan. Dosis steroid kumulatif adalah dosis keseluruhan prednison yang dikonsumsi sejak terapi dimulai hingga penelitian berlangsung (dinyatakan dalam milligram). Tinggi badan standar adalah TB untuk usia dan jenis kelamin berdasarkan baku WHO-National Center for Health and Statistic (NCHS). Persentil 50 dari baku WHO-NCHS dianggap sebagai seratus persen standar. Tinggi badan dikatakan mengalami hambatan apabila nilainya di bawah 90\%. Usia tulang didefinisikan sebagai deviasi dari usia kronologis (CA). ${ }^{7}$ Delta $(\Delta)$ usia tulang adalah hasil pengurangan usia kronologis dengan usia tulang. Jika hasilnya negatif maka usia tulang dinyatakan mengalami percepatan; sedang bila hasil nol, dikatakan normal. Apabila hasil positif, usia tulang dinyatakan mengalami keterlambatan. Deviasi dikatakan dalam batas normal, apabila nilai delta usia tulang berada di antara negatif dan positif 12 bulan. Jumlah relaps dihitung dalam 6 bulan atau 1 tahun.

Batasan yang digunakan untuk menjabarkan respons pasien terhadap terapi steroid seperti yang digunakan dalam penelitian lain. ${ }^{1}$ Semua pasien di ukur TB berdiri dengan menggunakan stadiometer yang sama (SMIC stadiometer, RRC, ketepatan 1 milimeter), tanpa alas kaki, diukur oleh residen yang sama. Pengukuran dilakukan dengan satuan sentimeter sedangkan persentase terhadap standar, seperti yang telah dijelaskan sebelumnya. Pengukuran diulang 3 kali, hasil rata-rata pengukuran dianalisis. ${ }^{8}$ Usia tulang didasarkan pada jumlah penulangan tulang karpalia tangan kiri pada foto rontgen posisi postero-anterior, kemudian dibandingkan dengan atlas standar modifikasi Greulych and Pyle, ${ }^{9}$ dibaca oleh ahli radiologi yang sama. Analisis regresi linier digunakan untuk menganalisis masing-masing hubungan antara dosis steroid kumulatif, lama terapi steroid dan jumlah relaps, dengan TB dan usia tulang. Data dianalisis menggunakan SPSS 9.0, dengan tingkat kemaknaan $p<0.05$.

\section{Hasil}

Antara 1 Januari 1998 dan 31 Juli 2000, terdapat 51 pasien SN yang dirawat. Dari jumlah tersebut hanya 16 yang memenuhi kriteria. Tabel 1 - 4 memperlihatkan distribusi karakteristik pasien yang diikutkan dalam penelitian ini. Semua subyek mempunyai status gizi baik. 
Sari Pediatri, Vol. 4, No. 2, September 2002

Tabel 1. Karakteristik 16 kasus Sindrom Nefrotik RSUP Denpasar Januari 1998 - Juli 2000

\begin{tabular}{lll}
\hline Variabel & & $\mathrm{N}$ \\
\hline Usia (tahun) & rerata & $7,29( \pm 3,3)^{*}$ \\
& rentang & $2,5-12,7$ \\
Rasio laki: perempuan & & $14: 2$ \\
\hline
\end{tabular}

* SB: simpang baku

Tabel 2. Status Relaps

\begin{tabular}{lll}
\hline Klinis & $\mathrm{N}$ \\
\hline Jumlah relaps & $\begin{array}{l}\text { rerata } \\
\text { rentang }\end{array}$ & $\begin{array}{l}4,9 \\
\text { Rasio } \frac{1-7}{\text { relaps sering }}\end{array}$ \\
relaps sering & $\frac{8}{8}$ \\
Rasio relaps sering & $\frac{15}{1}$ \\
\hline
\end{tabular}

Pada saat mendapat terapi steroid, terdapat 2 pasien yang telah mendapat siklofosfamid dengan dosis total $2800 \mathrm{mg}$ dan $1200 \mathrm{mg}$, masing masing selama 8 minggu dan 4 minggu. Pasien pertama mendapatkan siklofosfamid atas indikasi kejadian hipertensi sewaktu mendapat steroid, sedangkan pada pasien ke dua atas indikasi resisten steroid. Kedua pasien ini juga mendapat kaptopril dengan dosis total $90 \mathrm{mg}$ selama 3 hari. Siklofosfamid diberikan hingga terjadi remisi.

Analisis regresi linier sederhana menunjukkan tidak terdapat hubungan yang bermakna antara TB dan dosis kumulatif steroid $(\mathrm{r}=0.6, \mathrm{p}=0.55)$. Hubungan antara TB dan lama terapi steroid, juga tidak bermakna $(r=0.6$, $\mathrm{p}=0.56$ ). Hasil yang sama juga ditemukan pada hubungan antara usia tulang dengan dosis kumulatif steroid $(\mathrm{r}=0.17, \mathrm{p}=0.14)$, juga antara usia tulang dengan lama terapi steroid $(r=0.46, p=0,90)$.

Pada analisis regresi linier sederhana untuk melihat hubungan antara jumlah relaps dengan $\mathrm{TB}$, didapatkan hubungan yang tidak bermakna $(\mathrm{r}=0.16, \mathrm{p}=0.88)$, demikian juga tidak terdapat hubungan antara jumlah relaps dengan usia tulang $(\mathrm{r}=0.39, \mathrm{p}=0.20)$

Analisis regresi linier berganda untuk tiga variabel bebas memperkuat hasil sebelumnya, bahwa dosis kumulatif dan lama terapi steroid, serta jumlah relaps tidak memiliki hubungan dengan TB maupun usia tulang.
Tabel 3. Tinggi badan dan usia tulang

\begin{tabular}{lll}
\hline Variabel & & $\mathrm{N}$ \\
\hline Tinggi badan $(\mathrm{cm})$ & rerata & $120 \pm 18,25$ \\
& rentang & $88-150$ \\
Persentase tinggi badan & rerata & $97,5 \pm 4,8$ \\
terhadap standar & rentang & $89-107$ \\
Usia tulang (tahun) & rerata & $6,3 \pm 3,3$ \\
& rentang & $2-13$ \\
Persentase usia tulang & rerata & $84,6 \pm 15,8$ \\
terhadap usia kronologis & rentang & $57-118$ \\
Selisih usia kronologis & rerata & $8,3 \pm 9,7$ \\
dan usia tulang (bulan) & rentang & $-1-27$ \\
\hline
\end{tabular}

Tabel 4. Pengobatan steroid

\begin{tabular}{rll}
\hline Dosis steroid & & $\mathrm{N}$ \\
\hline $\begin{aligned} \text { Dosis kumulatif steroid } \\
(\mathrm{mg})\end{aligned}$ & $\begin{array}{l}\text { rerata } \\
\text { rentang }\end{array}$ & $4405 \pm 2730$ \\
$\begin{aligned} \text { Lama pengobatan } \\
\text { (bulan) }\end{aligned}$ & $\begin{array}{l}\text { rerata } \\
\text { rentang }\end{array}$ & $9,6 \pm 2.11 .460$ \\
\hline
\end{tabular}

\section{Diskusi}

Dalam keadaan fisiologis, steroid memainkan peran penting pada sintesis kartilago, namun pada pemberian dosis tinggi dan jangka waktu lama, steroid akan mempengaruhi pulsasi dan sekresi hormon pertumbuhan melalui peningkatan tonus hipotalamus, yang kemudian akan menekan $m$-RNA dari IGF-I di hati. Jika kadar hormon pertumbuhan dan IGF-I masih normal, maka efek samping akan terjadi melalui mekanisme di tingkat jaringan, berupa hilangnya sensitifitas cawan pertumbuhan. Steroid berperan sebagai agen katabolik dengan menekan sintesis kolagen melalui penekanan aktifitas IGF-I serta menghambat pertumbuhan progenitor osteosit, mitosis kartilago, terutama pada penderita $\mathrm{SN}$ dependen steroid. ${ }^{10,11}$

Efek samping steroid terhadap pertumbuhan, terutama ditentukan oleh lama terapi. Tsau, dkk. menemukan bahwa pemberian terapi steroid selama 6 bulan merupakan faktor penentu utama untuk terjadinya penekanan pada pertumbuhan. ${ }^{5}$ Dalam penelitian ini, dengan rerata lama terapi 9,6 bulan, hanya 1 pasien yang mempunyai TB berada di bawah 
standar TB berdasarkan umur dan jenis kelamin. Sedangkan dua pasien memiliki TB di atas 100\% standar. Rerata delta usia tulang $(+8,3$ bulan) menggambarkan maturasi skeletal umumnya terlambat, meski masih dalam batas normal. Namun demikian terdapat 2 pasien dalam masa pubertas dini, dengan usia tulang bahkan mengalami percepatan. Analisis statistik menunjukkan lama terapi ternyata tidak memiliki hubungan dengan TB dan usia tulang. Hal ini sesuai dengan penelitian Saha,dkk. yang mengobservasi 21 pasien dengan sindrom nefrotik dependen steroid selama 4 tahun, dan menemukan mereka memiliki kecepatan tumbuh normal dan tidak terdapat gangguan pertumbuhan pada akhir penelitian. ${ }^{11}$ Meski hasil penelitian sebelumnya mendapatkan penekanan usia tulang lebih sering didapatkan dibandingkan penekanan TB, terutama pada anak laki, pada penelitian kami didapatkan usia tulang masih dalam batas normal. Kami tidak dapat memastikan apakah hal ini disebabkan karena pemberian steroid dengan cara selang seling pagi hari. Cara pemberian ini cenderung mengurangi efek samping steroid dan menjaga kadar IGF-I dalam batas normal pada hari bebas steroid.

Hal lain yang perlu mendapat perhatian adalah kisaran umur subjek penelitian ini cukup lebar, sehingga terdapat perbedaan kecepatan pertumbuhan. Demikian juga lama observasi yang lebih pendek dibandingkan dengan penelitian lain yang serupa. Hal ini mungkin juga memberikan kontribusi pada pertumbuhan normal dan menyiratkan belum tampak efek samping steroid pada subjek penelitian. Namun demikian, peneliti lain melakukan observasi setelah 56 tahun pemakaian steroid dan menemukan hasil yang sama dengan penelitian ini. ${ }^{12-16}$

Efek samping steroid tergantung dari dosis harian dan dosis kumulatif. Dosis steroid $45 \mathrm{mg} / \mathrm{m}^{2} / \mathrm{hari}^{17}$ dan dosis kumulatif sebesar $2087 \mathrm{mg} / \mathrm{m}^{2} / \operatorname{tahun}^{18}$ akan menekan pertumbuhan dan maturasi skeletal pada pasien tanpa kelainan endokrin. Dalam penelitian ini, pasien menerima dosis steroid $60 \mathrm{mg} / \mathrm{m}^{2} /$ hari dengan dosis kumulatif 4405 mg untuk 9,6 bulan, didapatkan TB mereka tetap dalam batas normal, meski didapatkan 1 pasien di bawah normal. Usia tulang mengalami keterlambatan rata-rata 8,3 bulan, meskipun terdapat 2 pasien mengalami percepatan. Analisis statistik menunjukkan tidak terdapat hubungan antara TB dan usia tulang dengan dosis steroid. Hasil ini sesuai dengan penelitian oleh
Elzouki ${ }^{19}$ yang melakukan penelitian pada 37 pasien $\mathrm{SN}$ yang mendapat steroid sebanyak $2 \mathrm{mg} / \mathrm{kg} / \mathrm{hari}$ dilanjutkan dengan $10 \mathrm{mg} /$ hari setelah mencapai remisi, dan menemukan tidak terdapat penekanan pertumbuhan, sedangkan Foote ${ }^{20}$ menemukan TB pasien pra pubertas pada persentil 40, serta tidak mendapatkan hubungan antara dosis total dan TB. Ekim $^{21}$ dengan penelitiannya pada 12 pasien SN sensitif steroid mendapatkan TB dalam batas normal, sedang usia tulang terlambat, namun dalam batas normal. Di sisi lain, Steendijk ${ }^{22}$ dan Polito ${ }^{15}$ menemukan keterlambatan bermakna dibandingkan dengan kontrol. Frekuensi atau cara pemberian selang seling pagi hari akan menjaga ritme sirkadian steroid endogen dan memungkinkan hormon pertumbuhan bekerja pada malam harinya.

Beratnya penyakit dapat mempengaruhi pertumbuhan. Dalam penelitian ini, beratnya penyakit di refleksikan dengan jumlah relaps, namun kami tidak menemukan adanya hubungan antara TB dan usia tulang dengan jumlah relaps. Setelah terapi selama 714 bulan, separoh dari pasien dalam penelitian ini mengalami relaps sering, dengan rerata 4,9 kali. Hal ini sesuai dengan perjalanan alamiah penyakit SN dengan kelainan minimal, seperti pada penelitian Ekim. ${ }^{21}$ Ekim menemukan tidak ada hubungan antara tinggi badan dengan jumlah relaps. Penelitian ini memiliki beberapa kelemahan, antara lain penelitian ini merupakan penelitian retrospektif, jumlah subjek kecil, kisaran umur lebar, tidak terdapat data tinggi badan dan usia tulang sebelum penelitian dimulai. Status gizi didasarkan atas cara yang paling sederhana, yakni berat badan terhadap umur, demikian juga tinggi badan memakai standar internasional oleh karena belum adanya rujukan nasional untuk tinggi badan.

Kelemahan lain adalah, tidak terdapat kontrol terhadap faktor yang mempengaruhi tinggi badan dan usia tulang, seperti jenis nutrisi, tinggi bandan orangtua, serta status hormonal pasien. Dengan kisaran umur yang lebar, terdapat perbedaan kecepatan tumbuh antara masing-masing pasien. Demikian juga beratnya penyakit serta status gizi seharusnya diperhitungkan sebagai faktor yang mempengaruhi pertumbuhan. ${ }^{23,24}$ Meski steroid jangka panjang digunakan secara luas dalam praktek pediatri, seperti pada kasus SN, asma, juvenile arthritis rheumatoid dan penyakit inflamasi lain, penelitian ini merupakan penelitian pertama yang mengamati efek samping penggunaan steroid di RSUP Denpasar. 
Dalam penelitian ini telah di evaluasi sebanyak 16 pasien SN. Kejadian relaps cukup banyak, jadi meskipun dosis kumulatif steroid cukup tinggi, tidak didapatkan gangguan pertumbuhan kecuali keterlambatan usia tulang rata rata 8,3 bulan. Dalam penelitian ini, TB dan usia tulang tidak mempunyai hubungan dengan dosis kumulatif dan lama terapi steroid serta jumlah relaps. Untuk memperbaiki kelemahan penelitian ini, diperlukan penelitian prospektif untuk menentukan efek samping steroid terhadap pertumbuhan pasien SN. Meski dalam penelitian ini tidak didapatkan hubungan antara tinggi badan dan usia tulang dengan dosis kumulatif, lama terapi dan jumlah relaps, kita sebaiknya tetap harus mengawasi pasien dengan terapi steroid jangka panjang, karena steroid akan mempengaruhi kualitas hidup mereka secara individu.

\section{Daftar Pustaka}

1. Nash MA, Edelman CM, Burnstein J, Barnett HL. Minimal change nephrotic syndrome, diffuse mesangial cellularity, and focal glomerular sclerosis. Dalam: Edelman Jr $\mathrm{CM}$, penyunting. Pediatric kidney disease. Edisi ke-2. Boston: Little Brown and Co, 1992. h. 1267-71.

2. Hodson EM, Knight JF, Willis NS, Craig JC. Corticosteroid therapy for nephrotic syndrome in children (Cochrane review). Didapat dari: Cochrane Database Syst Rev 2000; 4:CD001533.

3. Scharer K, Essigmann HC, Schaefer F. Body growth of children with steroid-resistant nephrotic syndrome. Pediatr Nephrol 1999; 13:828-34.

4. Kitamura MD. Growth retardation in children with frequent relapsing nephrotic syndrome on steroid-improvement of height velocity after administration of immunosuppressive agent. Nippon Jinzo Gakkai Shi 1992; 34:117-24.

5. Tsau YK, Chen CH, Lee PI. Growth in children with nephrotic syndrome. Taiwan I Hsueh Hui Tsa Chih 1989; 88:900-6.

6. Rees L, Greene SA, Adlard P. Growth and endocrine function in steroid sensitive nephrotic syndrome. Arch Dis Child 1988; 63:484-90.

7. Karyomanggolo WT. Peran usia tulang pada penilaian anak perawakan pendek. Dipresentasikan pada Pendidikan Kedokteran Berkelanjutan Ilmu Kesehatan Anak XXVIII FKUI Jakarta, 16-17 Februari, 1993
8. Soetjiningsih. Perawakan pendek pada anak. Dipresentasikan dalam Seminar kelainan tumbuh kembang anak, Denpasar, 23 April, 1997

9. Meschan I, Farrer-Meschan RMF. The musculoskeletal system. Dalam: Analysis of roentgen signs in general radiology. Philadelphia: WB Saunders Co, 1973. h. 68-113.

10. Klaus G, Jux C, Fernandez P, dkk. Suppression of growth plate chondrocyte proliferation by corticosteroids. Pediatr Nephrol 2000; 14:612-5.

11. Saha MT, Laippala P, Lenko HL. Normal growth of prepubertal nephrotic children during long treatment with repeated courses of prednisone. Acta Paediatr 1998; 87:545-8

12. Adhikari M, Manikkam NE, Coovadia HM. Effects of repeated courses of daily steroids and of persistent proteinuria on linear growth in children with nephrotic syndrome. Pediatr Nephrol 1992; 6:4-9.

13. Polito C, Greco N, Opallo A, dkk. Alternate-day steroids affect carpal maturation more than radius, ulna and short bones. Pediatr Nephrol 1994; 8:480-2.

14. Tune BM, Mendoza SA. Treatment of the idiopathic nephrotic syndrome: regimens and outcomes in children and adults. J Am Soc Nephrol 1997; 8:824-32.

15. Polito C, Di Toro R. Delayed pubertal growth spurt in glomerulopathic boys receiving alternate day prednisone. Child Nephrol Urol 1992; 12:202-7.

16. Kashtan C, Melvin T, Kim Y. Long-term follow-up of patients with steroid dependent, minimal change nephrotic syndrome. Clin Nephrol 1988; 29:79-85.

17. Hyam JS, Carey DE. Corticosteroids and growth. J Pediatr 1988; 113:249-54.

18. Hyam JS, Moore RE, Leichtner AM, Carey DE, dkk. Relationship of type I procollagen to corticosteroid theraphy in children with inflammatory bowel disease. J Pediatr 1988; 112:893-8.

19. Elzouki AY, Jaiswal OP. Long-term, small dose prednisone therapy in frequently relapsing nephrotic syndrome of childhood. Effect on remission, statural growth, obesity and infection rate. Clin Pediatr 1988; 8:387-92.

20. Foote KD, Brocklebank JT, Meadow SR. Height attainment in children with steroid-responsive nephrotic syndrome. Lancet 1985; 2:917-9.

21. Ekim M, Tumer N, Ocal G, Yalcinkaya F. Effect of steroids on growth in children with steroid sensitive nephrotic syndrome. Child Nephrol Urol 1992; 12:10-4.

22. Steendijk R. Remarkable catch-up growth in boy with steroid-responsive nephrotic syndrome. Acta Endocrinol Suppl 1986; 79:8-12.

23. Travis LB, Chesney R, McEnery P, et al. Growth and glucocorticoids in children with kidney disease. Kidney Int $1978 ; 14: 365-8$.

24. Gafni RI, Baron J. Catch-up growth: possible mechanisms. Pediatr Nephrol 2000; 14:616-19. 